ks. Piotr Kroczek

\title{
List do rodzin Gratissimam sane jako wskazówka dla prawodawstwa państwowego $^{1}$
}

\section{Uniwersalna doniosłość Roku Rodziny i listu Gratissimam sane}

Kościół jako „sługa ludzkości” posłany przez Chrystusa do wszystkich ludzi ( $\mathrm{LG}^{3}$ 1) i wszystkich narodów (LG 24) wsparł ideę podjętą

$1 \quad$ Niniejszy artykuł został opracowany z uwzględnieniem referatu wygłoszonego przez autora na Międzynarodowej Konferencji zatytułowanej The family institution: identity, sovereignty, social dimension - on the 2oth anniversary of the Letter to Families from John Paul II „Gratissimam sane” 24-25 października 2014, Presov, Słowacja. Referat ten ukaże się w 2015 roku w pracy zbiorowej pod tytułem: Church teaching on marriage and family as an instruction for the state legislator in the context of Poland.

2 Paulus PP. VI, Homilia ad Patres Conciliares habita a Summo Pontifice, 7.12.1965 r., „Acta Apostolicae Sedis” [dalej: AAS] 58 (1966), s. 57.

3 Sacrosanctum Concilium Oecumenicum Vaticanum II, Constitutio dogmatica Lumen gentium de Ecclesia, 21.11.1964, AAS 57 (1965), s. 5-75; tekst łacińsko-polski: Sobór Watykański II, Konstytucja dogmatyczna o Kościele Lumen gentium, [w:] Sobór Watykański II, Konstytucje, dekrety, deklaracje, Poznań 1986, s. $146-265$. 
przez Organizację Narodów Zjednoczonych, aby rok 1994 ogłosić Międzynarodowym Rokiem Rodziny ${ }^{4}$. Jest to w pełni zrozumiałe, rodzina bowiem jest podstawową instytucją społeczności zarówno kościelnej, jak i państwowej. Kościół stoi na stanowisku, że rodzina stanowi jedno z najcenniejszych dóbr ludzkościs i jest ona naturalną i podstawową komórką społeczeństwa ${ }^{6}$.

List do rodzin Jana Pawła II Gratissimam sane wpisuje się w wiele innych enuncjacji kościelnych dotyczących tematu rodziny?.

4 Joannes Paulus PP. II, Litterae Gratissimam sane familiis datae ipso volvente sacro Familiae anno MCMXCIV, 2.02.1994, AAS 86 (1994), s. 868-925; tekst polski: Nauczanie Kościoła katolickiego [document elektroniczny], Wydawnictwo M, Kraków 2003 [dalej: LGS], tu nr 3.

5 Joannes Paulus PP. II, Adhortatio apostolica Familiaris consortio de Familiae Christianae muneribus in mundo huius temporis, 22.11.1981, AAS 74 (1982), s. 81-191; tekst polski: Jan Paweł II, Adhortacja apostolska Familiaris consortio, Wrocław 1994, tu nr 1.

6 Art. 16 ust. 3 Powszechnej Deklaracji Praw Człowieka z dnia 10.12.1948, [w:] Wybór dokumentów prawa międzynarodowego dotyczących praw człowieka, red. M. Zubik, Warszawa 2008, s. 11-16; art. 1o Międzynarodowego paktu praw gospodarczych, społecznych i kulturalnych otwarty do podpisu w Nowym Jorku 19.12.1966 (Dz.U. z 1977 r. Nr 38, poz. 167).

7 Zob. przykładowo Pius PP. XI, Litterae encyclicae Casti connubii de matrimonio christiano spectatis praesentibus familiae et societatis condicionibus, necessitatibus, erroribus, vitiis, 31.12.1930, AAS 22 (1930), s. 539-592; tekst polski: Pius XI, Encyklika o małżeństwie chrześcijańskim: Casti connubii, przeł. S. Bełch, London 1945; Joannes Paulus PP. II, Adhortatio apostolica Familiaris consortio de Familiae Christianae muneribus in mundo huius temporis, 22.11.1981, AAS 74 (1982), s. 81-191; tekst polski: Jan Paweł II, Adhortacja apostolska Familiaris consortio, Wrocław 1994; Pontificio Consiglio per la Famiglia, Famiglia e questioni etiche, Bologna 2004; Pontificio Consiglio per la Famiglia, La famiglia: dono 
Wspomniany dokument zawiera streszczenie katolickiej nauki dotyczącej małżeństwa i rodziny w kontekście występowania współczesnych szans i zagrożeń dla tych wspólnot.

List został skierowany przede wszystkim do chrześcijańskich rodzin, a także do tych, którzy z ramienia Kościoła są odpowiedzialni za rodziny: „Braci w biskupstwie, do duszpasterzy, rodzin zakonnych, osób konsekrowanych, ruchów i organizacji kościelnych" (zob. kan. 1063, kan. 1064, kan. 1067). Papież swoje słowo skierował także do wszystkich braci, którzy należą do wielkiej wspólnoty wierzących w jednego Boga, uczestniczących w wierze Abrahama oraz do tych, którzy są dziedzicami innych tradycji duchowych i religijnych, a także do każdego człowieka dobrej woli ${ }^{8}$ Oznacza to, papież uważa, iż jego list jest przesłaniem uniwersalnym i może być użyteczny w różnych okolicznościach i warunkach kulturowych, religijnych czy etnicznych.

Dwudziesta rocznica opublikowania tego dokumentu stanowi dobrą sposobność, aby przypomnieć niektóre myśli w nim zawarte i odczytać je jako wskazówki dla ustawodawcy państwowego9. Trzeba pamiętać, że takie pouczenie ze strony Kościoła wynika z jego głębokiego przekonania, że „przysługuje [mu] prawo głoszenia zawsze i wszędzie zasad moralnych, również w odniesieniu

e impegno speranza dell'umanità: atti del Congresso Internazionale Rio de Janeiro, 1-3 ottobre 1997, Città del Vaticano 1997; Pontificio Consiglio Per la Famiglia, Carta dei diritti della famiglia, (22.10.1983), [w:] Enchiridion Vaticanum. Documenti ufficiali della Santa Sede (1983-1985), vol. 9, Bologna 20oo, nr 538-552; polskie wydanie: Karta praw rodziny przedtożona przez Stolicę Apostolskq wszystkim ludziom, instytucjom $i$ władzom zainteresowanym misją rodziny $w$ świecie wspótczesnym, Katowice 2008.

\footnotetext{
8 LGS 23.

9 Zob. LGS 17 i 21.
} 
do porządku społecznego, oraz wypowiadania oceny o wszystkich sprawach ludzkich" (kan. 747 § 2) ${ }^{10}$. Takie działanie Kościoła jest także w pełni usprawiedliwione i nie narusza zasady rozdzielności państwa i Kościoła oraz autonomii i niezależności tych podmiotów (zob. art. 25 ust. 3 Konstytucji RP z 1997 r." ). Zarówno bowiem państwo, jak i Kościół zobowiązane są do pełnego poszanowania wspomnianych zasad we wzajemnych stosunkach, przy „współdziałaniu dla rozwoju człowieka i dobra wspólnego" (art. 1 Konkordatu) ${ }^{12}$.

Z drugiej strony katolicy sprawujący w państwie władzę ustawodawczą mają kanoniczny obowiązek popierania dobra wspólnego (GS³ 26). Mają oni czynić wysiłki, aby „swoją działalność przepoić duchem ewangelicznym” i mieć w tym działaniu na uwadze naukę przedstawioną przez Nauczycielski Urząd Kościoła (kan. 227). Celem katolickich parlamentarzystów powinno być przepojenie i udoskonalenie duchem ewangelicznym porządku doczesnego, za który są odpowiedzialni. W ten sposób w wykonywaniu świeckich

10 Cytowane w tym artykule kanony odnoszą się do Codex Iuris Canonici auctoritate Ioannis Pauli PP. II promulgatus, AAS 75 (1983), cz. 2, s. 1-318, a ich tłumaczenie pochodzi z przekładu zatwierdzonego przez Konferencję Episkopatu Polski, Kodeks prawa kanonicznego, tekst łacińsko-polski, Poznań 1984. Przywołane kanony odnoszą się do tego aktu normatywnego.

11 Konstytucja Rzeczypospolitej Polskiej z dnia 2 kwietnia 1997 r. (Dz.U. Nr 78, poz. 483 ze sprost. i z późn. zm.).

12 Konkordat między Stolicą Apostolską i Rzecząpospolitą Polską podpisany w Warszawie dnia 28 lipca 1993 r. (Dz.U. z 1998 r. Nr 51, poz. 318).

13 Sacrosanctum Concilium Oecumenicum Vaticanum II, Constitutio pastoralis Gaudium et spes de Ecclesia in mundo huius temporis, 7.12.1965, AAS 58 (1966), s. 1025-1115; tekst łacińsko-polski: Sobór Watykański II, Konstytucja duszpasterska o Kościele w świecie współczesnym Gaudium et spes, [w:] Sobór Watykański II, Konstytucje, dekrety, deklaracje, Poznań 1986, s. 830-987. 
funkcji dadzą oni szczególne świadectwo Chrystusowi (zob. kan. 225 § 2). Taką postawę promowali także polscy biskupi, stanowiąc w Dyrektorium duszpasterstwa rodzin, że „katolik pełniący funkcje publiczne posła, radnego czy innego urzędnika jest w sumieniu zobowiązany do popierania polityki prorodzinnej"14.

\section{Rola prawa stanowionego w regulowaniu spraw rodziny}

Prawdą jest, że „L’umanità non è «senza legge»” („Ludzkość nie jest «pozbawiona prawa»"). Prawo bowiem towarzyszy ludzkości przez całą jej historię¹. Ma ono wielką wartość. Po pierwsze dlatego, że prawo samo jest wartością. Jest elementem ogólnej kultury i istotną zdobyczą cywilizacyjną. Prawo, zarówno tworzone oddolnie, jak i stanowione odgórnie, dzięki tradycji prawnej jest swoistym „bankiem pamięci” całych cywilizacji i poszczególnych społeczności, dzięki któremu niesione są przez historię określone wypracowane i sprawdzone rozwiązania społeczne ${ }^{17}$. Po drugie prawo jest wartością, bowiem istnieje w odniesieniu do innych

14 Konferencja Episkopatu Polski, Dyrektorium duszpasterstwa rodzin, dokument przyjęty podczas 322 Zebrania Plenarnego Konferencji Episkopatu Polski 1.05.2003, Warszawa 2003, 83.

15 Messaggio del Santo Padre Benedetto XVI per la Celebrazione della XLI Giornata Mondialedella Pace, 1.01.2008, AAS 100 (2008), s. 44; polskiettumaczenie: Orędzie Ojca Świętego Benedykta XVI na Światowy Dzień Pokoju, 1.01.2008 r., www.vatican.va/holy_father/benedict_xvi/messages/peace/documents/hf_benxvi_mes_20071208_xli-world-day-peace_pl.html (11.01.2014).

16 R. Sobański, Prawo jako wartość, „Prawo Kanoniczne” 42 (1999) nr 3-4, S. 11 .

17 Zob. P. Kroczek, Pamięć i tożsamość w prawie kanonicznym, [w:] Lex tua veritas, red. P. Majer, A. Wójcik, Kraków 2010, s. 461-466. 
wartości, tworząc system wartości. Prawo spełnia wobec tych wartości określoną funkcję - jest narzędziem do ich realizacji ${ }^{18}$. Regulacje prawne chronią i bronią wartości, które mają znaczenie z punktu widzenia prawodawcy czy adresatów prawa.

Powiązanie norm prawnych z wartościami otwiera kolejne zagadnienie, jakim są subiektywne podstawy decyzji prawodawczych. Trzeba pamiętać, że prawodawca nigdy nie może stanąć poza kulturą, którą przejął i która stała się jego własną. Dotyczy to także kultury prawnej. Ustanawiający prawo zawsze uwarunkowany jest swoim doświadczeniem życiowym, ale także światopoglądem czy wyznawaną religią. Nie może on bowiem wyobcować się z samego siebie.

Słuszne zobowiązanie do zachowania bezstronności w sprawach przekonań religijnych, światopoglądowych i filozoficznych ustawodawców (art. 25 ust. 2 Konstytucji RP z 1997 r.) można wypełnić jedynie poprzez autentyczną subiektywność - „Genuine objectivity is the fruit of authentic subjectivity” ${ }^{19}$. Owa „autentyczna subiektywność” oznacza, że prawodawca musi „znać siebie” i „być sobą”. W myśl tego założenia w działanie prawodawcze powinien być zaangażowany człowiek - prawodawca świadomy swoich ograniczeń i możliwości, osobistych preferencji i uprzedzeń. Nie powinien on uciekać od siebie samego, lecz powinien podchodzić do siebie inteligentnie z rozsądkiem, uwagą i odpowiedzialnością²

Zarówno prawo państwowe, jak i prawo kościelne musi uznawać podstawowe prawa człowieka wypływjące z ludzkiej natury.

18 R. Sobański, Prawo jako wartość, „Prawo Kanoniczne” 42 (1999) nr 3-4, S. 20.

19 B. Lonergan, Philosophy of God and theology, Philadelphia 1973, s. 44: „Obiektywność jest owocem autentycznej subiektywności”.

20 B. Lonergan, Method in theology, New York 1972, s. 265. 
Przez prawo to, kierujące się nie pobudkami partykularnymi czy ideologicznymi, lecz zawsze dobrem człowieka, ma być także kreowana rzeczywistość. Takie prawo, będąc regulatorem zachowań ludzkich, ma w przedmiocie rodziny bardzo odpowiedzialne zadanie do wypełnienia. Znacząca rola instytucji małżeństwa w społeczeństwie powoduje, że nie może być ono uznane za instytucję tylko prywatną ${ }^{21}$. Zatem ingerencja społeczności w kształt i funkcjonowanie rodziny jest, w pewnym zakresie i do pewnego stopnia, w pełni uzasadniona.

Nie wolno jednak z drugiej strony zapomnieć, że rola prawa stanowionego zawsze musi być rolą pomocniczą wobec kształtu, funkcji i zadań, które wykonuje rodzina na podstawie Bożego prawa naturalnego. „Rodzina jest bowiem takim społeczeństwem, które nie dysponuje wszystkimi środkami nieodzownymi do realizacji własnych celów”22. Jan Paweł II dobitnie stwierdził w liście, że „wszędzie tam, gdzie rodzina jest samowystarczalna, należy ją pozostawić samej sobie; co więcej, interwencjonizm państwowy byłby w tym zakresie szkodliwy, byłby wyrazem nie poszanowania, a deptania praw rodziny. Pomoc państwa zaczyna się dopiero tam, gdzie rodzina naprawdę sobie nie wystarcza”23. Także pomoc w postaci regulacji spraw rodzinnych ma być ograniczona do niezbędnego minimum. Niedopuszczalne jest działanie prawodawcze nacechowanie prawodawczym i administracyjnym idealizmem, to znaczy apriorycznym przekonaniem, że każda regulacja prawna kształtuje rzeczywistość i zmienia ją w pożądanym przez prawodawcę kierunku. Pomocniczość regulacji prawnych ma dopełniać,

21 Zob. M. Rymsza, Małżeństwo nie jest sprawq prywatnq, „Więź” 11-12 (2009), s. 57-72.
22 LGS 17,
23 LGS 17. 
a równocześnie potwierdzać fundamentalny charakter naturalnych, a co za tym idzie niezbywalnych praw rodziny ${ }^{24}$. Kościół ostrzega, że „zbyt daleko posunięta interwencja państwa może zagrażać osobistej wolności i inicjatywie. Nauczanie Kościoła wypracowało zasadę pomocniczości. Według niej «społeczność wyższego rzędu nie powinna ingerować $w$ wewnętrzne sprawy społeczności niższego rzędu, pozbawiając ją kompetencji, lecz raczej powinna wspierać ją w razie konieczności i pomóc w koordynacji jej działań z działaniami innych grup społecznych, dla dobra wspólnego»" (KKK $\left.{ }^{25} \mathrm{nr} 1883\right)$.

Ustawodawca powinien przyjąć, że choć rodzina może podlegać stanowionym przez niego regulacjom, to jednak „rodzina jest społecznością najmocniej «ugruntowaną» i w sposób sobie właściwy społecznością suwerenną” ${ }^{26}$. Papież podkreśla, że „rodzina jest podmiotem bardziej niż jakakolwiek inna społeczność. Jest podmiotem bardziej niż naród, niż państwo, niż społeczeństwo nie mówiąc już o różnych formach międzynarodowych organizacji” ${ }^{27}$. Zasada suwerenności instytucji rodziny pozwala - zdaniem papieża - mówić o prawach rodziny, które „nie są tylko matematyczną sumą praw osoby. Rodzina bowiem jest czymś więcej niż każdy z osobna człowiek. Jest wspólnotą rodziców i dzieci, bywa nieraz wspólnotą wielu pokoleń. Dlatego też jej podmiotowość domaga się własnych specyficznych praw"28. Wyraz tego przekonania dała Stolica Apostolska, publikując w roku 1983 Kartę Praw Rodziny.

24 Por. LGS 16.

25 Katechizm Kościoła katolickiego, Poznań 2002.

26 LGS 17.

27 LGS 15.

28 LGS 17. 


\section{Niektóre wskazówki płynące $z$ Listu do rodzin}

\subsection{O znaczeniu suwerennej rodziny dla społeczeństwa}

Pierwsza wskazówka, jaka płynie z Listu do rodzin i ma znacznie dla prawodawcy, jest związana $\mathrm{z}$ tym, że rodzina powinna mieć poczucie własnej godności, suwerenności i znaczenia dla całego społeczeństwa. Papież pisze, że „Naród prawdziwie suwerenny i duchowo mocny jest zawsze złożony $\mathrm{z}$ mocnych rodzin: rodzin świadomych swojego powołania i posłannictwa w dziejach. W centrum tych wszystkich spraw i zadań stoi zawsze rodzina. Jakiekolwiek odsunięcie jej na dalszy plan, wycofanie z przysługującej jej w społeczeństwie pozycji musi oznaczać niszczenie autentycznej substancji społecznej" ${ }^{29}$. Takie poczucie może dać rodzinie prawo zapewniające jej dużą autonomię w sprawach, w których z powodzeniem może ona działać sama. Regulacje prawne powinny chronić niezależność rodzin i nie dopuszczać, aby obce podmioty - takie jak urzędnicy państwowi, samorządowi - ingerowały w życie rodzinne bez konieczności zabezpieczenia słusznych praw członków rodziny lub rodziny jako całości ${ }^{30}$. Wydaje się, że w założeniach ustawodawca polski jest przekonany o słuszności tego kościelnego postulatu i uznaje, że rodzina jest „samodzielną instytucją ponoszącą główną

\section{LGS 17.}

30 Zob. art. 1123 ustawy z dnia z 25 lutego 1964 r. Kodeks rodzinny i opiekuńczy (tj. Dz.U. z 2012 r., poz. 788 z późn. zm.) [dalej: k.r.o.]: „Umieszczenie dziecka w pieczy zastępczej powinno nastąpić po wyczerpaniu wszystkich form pomocy rodzicom dziecka, o których mowa w przepisach o wspieraniu rodziny i systemie pieczy zastępczej, chyba że dobro dziecka wymaga zapewnienia mu niezwłocznie pieczy zastępczej”. 
odpowiedzialność za kształtowanie warunków życia i los swoich członków" (u.s.p.p.r.'31).

Oczywiście z drugiej strony przekonanie o suwerenności rodziny oraz pomocniczej roli stanowionych dla rodziny i ze względu na nią praw nie może powodować paraliż w niesieniu koniecznej i skutecznej pomocy rodzinie przeżywającej trudności i w jej szczególnej ochronie przez instytucje powołane do tak ukierunkowanych działań. Pewien interwencjonizm państwa jest bowiem konieczny. Jednakże „problemem nierozstrzygniętym pozostaje precyzyjne określenie, co jest już patologią wymagającą ingerencji państwa”’2.

\subsection{O heteroseksualności małżeństwa}

Do niedawna wydawać się mogło, że wskazywanie na konieczność heteroseksualności małżeństwa jest zbytecznym zabiegiem. Nie zwykło się bowiem podważać tej oczywistej prawdy wypływającej, zdaniem Kościoła, z prawa Bożego naturalnego, potwierdzonego przez Boże prawo stanowione (zob. Rdz 1, 27-28; Rdz 2, 23-24) 33 oraz prawo kanoniczne (kan. 1055 § 1, por. kan. 1057 § 2), że matżeństwo to związek kobiety i mężczyzny.

Także powszechnie prawo państwowe respektowało prawo Boże w tym zakresie. Tradycja prawa rzymskiego, poważająca małżeństwo jako bardzo ważną społecznie instytucję, uważała, że

31 Uchwała Sejmu Rzeczypospolitej Polskiej z dnia 30 sierpnia 1996 r. w sprawie polityki państwa na rzecz rodzin (M.P. Nr 55, poz. 502).

32 P. Kroczek, Wychowanie: optyka prawa polskiego i prawa kanonicznego, Kraków 2013, s. 53.

33 W. Góralski, Prawo Boże jako źródto kościelnego prawa matżeńskiego w Kodeksie Prawa Kanonicznego Jana Pawła II, [w:] W. Góralski, Studia nad małżeństwem i rodzina, Warszawa 2007, s. 17. 
małżeństwo to związek mężczyzny i kobiety ${ }^{34}$. Takie ujęcie małżeństwa weszło w kulturę prawną Europy i jest wciąż obecne w aktach prawa międzynarodowego (zob. art. 12 Konwencji o ochronie praw człowieka) 35 i aktach prawnych państwowych (zob. art. 18 Konstytucji RP z 1997 r. i art. 1 k.r.o.).

Obecnie jednak odmienność płci jako przesłanka konieczna do zawarcia małżeństwa jest kwestionowana w licznych postulatach de lege ferenda, które w wielu krajach doczekały się realizacji ${ }^{3}$. Wiele aktów normatywnych regulujących sprawę małżeństwa i rodziny zawiera przepisy stanowiące wprost, że małżeństwem jest także związek osób tej samej płcii

34 Iustiniani digesta, [w:] Corpus Iuris Civilis, editio stereotypa quinta, a cura di Th. Momsen, vol. 1, Berlolini 1889, s. 1-873, tu: 23, 2, 1: „Nuptiae sunt coniunctio maris et feminae et consortium omnis vitae, divini et humani iuris communicatio”; Iustiniani institutiones, [w:] Corpus Iuris Civilis, editio stereotypa quinta, a cura di P. Krüger, vol. 1, Berlolini 1889, p. 1-56, tu: 1, 9, 1: „Nuptiae autem sive matrimonium est viri et mulieris coniunctio, individuam consuetudinem vitae continens”, zob. szeroko o tym pisze L. M. Kuryłowicz, Wokół istoty małżeństwa rzymskiego, [w:] Finis legis Christus. Księga pamiątkowa W. Góralskiego, t. 2, red. J. Wroceński, K. Krajczyński, Warszawa 2009, s. 1149-1152.

35 Konwencja o ochronie praw człowieka i podstawowych wolności sporządzona w Rzymie 4.11.1950 (Dz. U. z 1993 r. Nr 61, poz. 284).

36 Te państwa to Belgia, Dania, Holandia, Francja, Portugalia, Hiszpania, Szwecja, Anglia i Walia, zob. na ten temat: P. Szukalski, Rejestrowane związki osób tej samej płci we współczesnej Europie, „Roczniki Socjologii Rodziny” 21 (2011), s. 169-184; Legal recognition of same-sex relationships in Europe: national, cross-border and European perspectives, ed. K. Boele-Woelki, A. Fuchs, Cambridge 2012.

37 Zob. art. 30 ust. 1 holenderskiego Burgerlijk Wetboek: „Een huwelijk kan worden aangegaan door twee personen van verschillend of van gelijk geslacht" 
W Liście do rodzin papież odnosi się wprost do omawianego zagadnienia. Pisze, że „małżeństwo, leżące u podstaw instytucji rodzinnej, ustanowione jest dzięki przymierzu, przez które «mężczyzna i kobieta tworzą ze sobą wspólnotę całego życia, skierowaną ze swej natury do dobra małżonków oraz do zrodzenia i wychowania potomstwa» (kan. 1055 § 1). Tylko taki związek może być uznany i potwierdzony społecznie jako «małżeństwo». Nie mogą być uznane społecznie jako małżeństwo inne związki międzyludzkie, które tym warunkom nie odpowiadają, choć dzisiaj istnieją takie tendencje, bardzo groźne dla przyszłości ludzkiej rodziny i społeczeństw" ${ }^{8}$.

\subsection{O zagrożeniach płynących}

\section{$\mathrm{z}$ ideologii gender}

Zwykle słowa gender używa się na oznaczenie płci kulturowej, czyli płci uwarunkowanej przez społeczeństwo poprzez określone role, zachowania, aktywności i atrybuty, jakie dane społeczeństwo uznaje za odpowiednie dla mężczyzn i kobiet ${ }^{39}$. Genderyzm jako ideologia promuje zasady sprzeczne z rzeczywistością i integralnym pojmowaniem natury człowieka, twierdzi bowiem, że płeć biologiczna nie ma znaczenia społecznego i że liczy się przede

\footnotetext{
(„Małżeństwo może być zawarte przez osoby o różnej płci lub tej samej płci”), www. wetboek-online.nl/wet/BW1.html (29.01.204).

38 LGS 17.

39 World Health Organization, What do we mean by „sex” and "gender”?, www.who.int/gender/whatisgender/en/index.html (9.01.2014); zob. także art. 3c Konwencji Rady Europy w sprawie zapobiegania i zwalczania przemocy wobec kobiet i przemocy domowej, www.europapraw.org/files/2011/10/konwencja_PL.pdf. (9.01.2014).
} 
wszystkim płeć kulturowa, którą człowiek może swobodnie modelować i definiować, niezależnie od uwarunkowań biologicznych ${ }^{40}$.

Papież, jakby przeczuwając niebezpieczeństwa związane z tą ideologią, pisze, że „poprzez małżeńską komunię osób mężczyzna i kobieta dają początek rodzinie. Z rodziną zaś wiąże się genealogia każdego człowieka: genealogia osoby. Ludzkie rodzicielstwo zakorzenione jest w biologii, równocześnie zaś przewyższa ją” ${ }^{41}$. A w innym miejscu: „Gdy z małżeńskiej jedności dwojga rodzi się nowy człowiek, to przynosi on z sobą na świat szczególny obraz i podobieństwo Boga samego: w biologię rodzenia wpisana jest genealogia osoby" ${ }^{42}$. Podkreślanie biologicznej różnicy płci jako czynnika fundamentalnego dla budowania małżeństwa i rodziny oraz spełniania funkcji prokreacyjnych i wychowawczych jest konieczne i musi być wzięte pod uwagę przy stanowieniu prawa ${ }^{43}$.

\subsection{O stosunkach pomiędzy rodzicami a dziećmi}

Ustawy państwowe zawierają zwykle pewne regulacje dotyczące stosunków pomiędzy rodzicami a dziećmi. Unormowania dotyczą obowiązków oraz praw rodziców względem dzieci i vice versa. Przykładowo uregulowana jest władza rodzicielska, kontakty pomiędzy tymi osobami, ich zobowiązania o charakterze alimentacyjnym (zob. art. 87-144 ${ }^{1}$ k.r.o.). Analiza polskich przepisów może nasunąć uwagę o widocznej w prawodawstwie tendencji do nadmiernej regulacji stosunków rodziców i dzieci. Przykładowo

40 List pasterski na Niedzielę Świętej Rodziny 2013 roku, http://episkopat.pl/ dokumenty/listy_pasterskie/5545.1,List_pasterski_na_Niedziele_Swietej_Rodziny_2013_roku.html (9.01.2014).

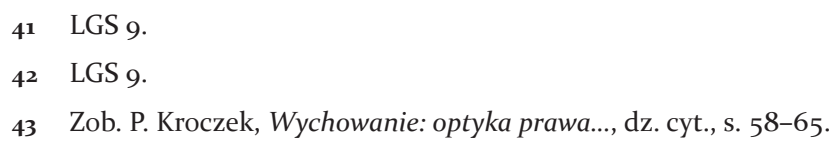


redakcje niektórych przepisów zawierających normy dotyczące obowiązku rodziców i dzieci do wzajemnego szacunku i wspierania się (art. 87 k.r.o.) ${ }^{44}$ czy obowiązku posłuszeństwa dziecka wobec rodziców (art. 95 § 2 k.r.o.) ${ }^{45}$ wskazują, że ustawodawca próbuje nadać walor normatywny relacjom, które z natury rzeczy wymykają się prawnym normom.

Papież z kolei poucza, że żaden przepis prawny regulujący stosunki rodzinne nie będzie skuteczny, jeżeli zabraknie postawy posłuszeństwa nakazowi czwartego przykazania Bożego „Czcij ojca twego i matkę twoją” (Wj 20, 12). „Trzeba ukazywać ważność tego przykazania - pisze Jan Paweł II - również dla nowożytnego systemu praw człowieka. Prawa przemawiają językiem prawniczym. Bóg natomiast mówi: „czcij”. Otóż wypada zauważyć, iż wszystkie „prawa człowieka” mogą być kruche i nieskuteczne, jeżeli u podstaw zabraknie tego „czcij”. Jeżeli zabraknie czci, inaczej mówiąc: afirmacji człowieka dlatego, że jest człowiekiem, że jest „tym człowiekiem,

44 Por. I. Ignatowicz, Art. 87, [w:] Kodeks rodzinny i opiekuńczy. Komentarz, red. K. Pietrzykowski, Warszawa 2012, nb. 6 - „Artykuł 87 normuje wzajemny obowiązek szacunku i wspierania się przez rodziców i dzieci”; inny pogląd zob. K. Gromek, Art. 87, [w:] K. Gromek, Kodeks rodzinny i opiekuńczy, Warszawa 2013, nb. 2 - „Obowiązek z art. 87 ma charakter deklaratoryjny i w istocie rzeczy nie rodzi skutków prawnych. [...] Zawiera on normę z zakresu moralności i dobrego obyczaju, dobrej wiary, czyli w rzeczywistości można go zaliczyć do zasad współżycia społecznego jako zasadę wzajemnego szacunku i wsparcia”.

45 Por. K. Gromek, Art. 95, [w:] Kodeks rodzinny i opiekuńczy, Warszawa 2013, nb. 3 - „Posłuszeństwo dziecka wobec jego rodziców jest obowiązkiem dziecka wynikającym z władzy rodzicielskiej”; inny pogląd zob. J. Strzebińczyk, Art. 95, [w:] System Prawa Prywatnego, t. 12, red. T. Smyczyński, Warszawa 2003, s. 251 - [Artykuł ten jest] „modelowym zapisem, postulowaną przez legislatora postawą dziecka”. 
wówczas same prawa nie wystarczą" ${ }^{46}$. Papież przestrzega przed nadmierną nadzieją pokładaną w stanowionych regulacjach: „Epoce, w której żyjemy - przy wszystkich i licznych deklaracjach typu prawnego - grozi w jakiejś mierze «wyobcowanie». [...] wyobcowanie z tego wszystkiego, co na różne sposoby należy do pełnego bogactwa człowieka. Odnosi się to również do rodziny”47.

\title{
3.5. O pracy zarobkowej oraz pracy wewnątrz rodziny
}

Praca jest jednym z tych aspektów życia człowieka, „aspektem odwiecznym i pierwszoplanowym, zawsze aktualnym i wciąż na nowo domagającym się, by o niej myśleć i świadczyć"48. Dlatego też temat ludzkiej pracy jest obecny w wielu enuncjacjach Kościoła ${ }^{49}$.

W kontekście rodziny Jan Paweł II pisze w liście, iż wśród praw człowieka dotyczących rodziny w sposób pośredni szczególne znaczenie ma prawo do pracy ${ }^{50}$. Zdaniem papieża państwo - nie wyłączając prywatnych inicjatyw - ma do spełnienia bardzo dużą rolę w tym, aby zapewnić realizację tego prawa do pracy. Pomoc państwa wyraża

\author{
46 LGS 15. \\ 47 LGS 15. \\ 48 Joannes Paulus PP. II, Litterae encyclicae Laborem exercens de labore huma-
} no, 14.09.1981, AAS 73 (1981), s. 577-647; tekst polski: Jan Paweł II, Encyklika Laborem exercens, [w:] Nauczanie Kościoła katolickiego, dz. cyt., 1.

49 Zob. przykładowo Encyklika Rerum novarum papieża Leona XIII z 15.05.1891, Leonis XIII P.M. Acta, XI, Romae 1892, s. 97-144; Encyklika Piusa XI, Quadragesimo Anno z 15.05.1931, AAS 23 (1931), s. 177-228, Encyklika Jana XXIII Mater et Magistra z 15.05.1961, AAS 53 (1961), s. 401-464; Encyklika Pawła VI Populorum progressio z 26.03.1967, AAS 59 (1967), s. 257-299, Encyklika Jana Pawła II Laborem exercens z 14.09.1981, AAS 73 (1981), s. 577-647, Encyklika Jana Pawła II Sollicituto rei socialis z 30.12.1987, AAS 8o (1980), s. 513-586.

50 Por. LGS 17. 
się w podejmowaniu odpowiednich środków dotyczących świata pracy ${ }^{51}$. Papież wzywa, aby stanowiący prawo znaleźli właściwe rozwiązania w tej dziedzinie, „bezrobocie [bowiem] stanowi w naszych czasach jedno z najpoważniejszych zagrożeń dla życia rodzinnego"s2.

Papież porusza także zagadnienie pracy kobiet wewnątrz rodziny i podkreśla jej ważność i ciężar. Pisze, że „praca ta powinna być gruntownie dowartościowana. Trud każdej kobiety związany z wydaniem na świat dziecka, z jego pielęgnowaniem, karmieniem, wychowaniem, zwłaszcza w pierwszych latach, jest tak wielki, że nie może mu dorównać żadna praca zawodowa”š. Postuluje on także dwie sprawy. Pierwsza jest taka, że praca w domu powinna „odzyskać należne zrozumienie w obrębie obowiązującego prawa pracy”54. A drugi postulat brzmi - „ażeby macierzyństwo kobiet zostało zrozumiane jako wystarczający tytuł do odpowiedniego wynagrodzenia, niezbędnego do utrzymania rodziny w tej bardzo ważnej fazie jej egzystencji”s5.

\section{Podsumowanie}

Obecnie w sytuacji zagrożenia instytucji rodziny widać, jak bardzo rodzina musi być wspomagana przez tych, którzy jako stanowiący prawo są odpowiedzialni za społeczność, dla której dobra wykonują działania legislacyjne.

Jest prawem i obowiązkiem Kościoła zabieranie głosu w sprawach rodziny, upominanie sięo jej prawa jako instytucji w pewnym sensie suwerennej i sugerowanie państwowym ustawodawcom takich rozwiązań prawnych, które będą uwzględniać dobro rodziny

51 Por. LGS 17.

52 LGS 17.

53 LGS 17.

54 LGS 17.

55 LGS 17. 
nie tylko w kontekście katolickich rodzin, ale całego społeczeństwa. Z kolei katolicy sprawujący władzę ustawodawczą mają obowiązek płynący z wiary takiego działania, które będzie realizacją nauczania Kościoła na temat rodziny. To dwutorowe działanie jest nieodzowne dla dobra całego społeczeństwa.

\section{SUMMARY}

\section{Letter to families from pope John Paul II Gratissimam sane as a guide for state legislation}

The 2oth anniversary of the publication of the Letter to families from Pope John Paul II Gratissimam sane is a great opportunity to recall the document and to bring to light some thoughts on family that would be useful hints for those who bear the legislative power. The paper presents five important ideas on marriage and family that must be, from catholic point of view, in some way present in law. The ideas concern: marriage as sovereign society, marriage as heterosexual union, the threats of gender ideology for the family, the proper relations between the parents and children, and the professional work and the work within the family unit. The Church has the right and duty „always and everywhere to proclaim moral principles, even in respect of the social order" (can. $747 \S 2$ ), and the faithful are "to ensure that their actions are permeated with the spirit of the Gospel, and they are to heed the teaching of the Church proposed by the magisterium" (can. 227).

Keywords: Gratissimam sane, John Paul II, family, marriage, law, legislation, Poland

ks. Piotr Kroczek, List do rodzin „Gratissimam sane” jako wskazówka dla prawodawstwa państwowego, [w:] Prawa dziecka: perspektywa Kościoła, red. ks. Piotr Kroczek, Kraków 2015, s. 81-97 (Annales Canonici Monographiae, 3).

DOI: http://dx.doi.org/10.15633/9788374384353.06 